\title{
PENGEMBANGAN MEDIA PEMBELAJARAN FISIKA BERBASIS ANIMASI KOMPUTER UNTUK SEKOLAH MENENGAH ATAS BERBASIS MACROMEDIA FLASH 8
}

\author{
Arif Rahman Aththibby \\ Program Studi Pendidikan Fisika Universitas Muhammadiyah Metro \\ E-Mail: aththibby@yahoo.com
}

\begin{abstract}
The research was motivated by the learning process of physics is less interest, but phyisics learning will be easier to accepted with students if the learning process is packed more interesting. This study aimed to make the physics learning media based computer animation from the topic of Newton laws used software Macromedia Flash 8 , and to know the validation of physics learning media based computer animation. This media was conducted by ADDIE model. The result of this study showed that: 1) it has been made the physics learning media based computer animation, 2) general assesment of the obtained result are very good products, making it feasible to use in their physics lesson in senior high school,.
\end{abstract}

Keyword: Development Media Based Computer Animation

\section{PENDAHULUAN}

Belajar Fisika bukan hanya sekedar tahu matematika, tetapi lebih jauh anak didik diharapkan mampu memahami konsep yang terkandung di dalamnya, menuliskannya ke dalam parameter-parameter atau simbolsimbol fisis, memahami permasalahan serta menyelesaikannya secara matematis. Tidak jarang hal inilah yang menyebabkan ketidaksenangan anak didik terhadap mata pelajaran ini menjadi semakin besar (Sugiharti, 2005). Sedangkan menurut Prabu dan Markus (2006), penggunaan media visual dalam proses pembelajaran fisika dapat menjembatani materi yang bersifat abstrak menjadi konkrit. Hal ini meningkatkan motivasi belajar fisika dalam diri siswa yang berimbas pada meningkatnya pemahaman terhadap materi yang diajarkan dan merangsang siswa untuk selalu mencari informasi-informasi yang berhubungan dengan pelajaran fisika. Gagne (1970) menyatakan bahwa media adalah berbagai jenis komponen dalam lingkungan siswa yang dapat merangsangnya untuk belajar. Sementara itu Brings (1970), berpendapat bahwa media adalah segala alat fisik yang dapat menyajikan pesan serta merangsang siswa untuk belajar (Sadiman, 1984: 6).

Penekanan pada aspek pernaharnan dan pengernbangan keterampilan berpikir dalam pernbelajaran fisika akan sangat membantu daya ingat siswa terhadap rumus-rumus fisika yang dipelajari (Mundilarto, 2003). Pernahaman terhadap suatu rumus fisika yang pada hakikatnya menggarnbarkan saling keterkaitan antara beberapa konsep fisika akan rnernbuat lebih mudah bagi siswa untuk dapat rnengingatnya kembali dan apabila diperlukan dengan mudah dapat menjabarkannya lagi.

Dalam penelitian ini akan dirancang media pembelajaran fisika berbasis animasi komputer materi 
pokok bahasan hukum-hukum Newton tentang gerak. Selain itu akan diteliti pula tentang kelayakan media tersebut sesuai atau tidak dengan kriteria kelayakan media pembelajaran.

Hasil dari penelitian ini diharapkan dapat bermanfaat dengan menghasilkan CD pembelajaran fisika dalam pokok bahasan hukum-hukum Newton tentang gerak. Selain itu, animasi komputer yang dihasilkan dapat dijadikan sebagai bahan pertimbangan dalam menentukan media yang menarik dalam pelaksanaan proses pembelajaran.

\section{METODE PENELITIAN}

Subjek dalam penelitian ini adalah media pembelajaran berbasis animasi komputer untuk siswa SMA kelas X pokok bahasan hukum-hukum Newton tentang gerak. Materi bahan ajar mengacu pada kurikulum yang saat ini berlaku yaitu KTSP (Kurikulum Tingkat Satuan Pendidikan).
Peralatan yang digunakan dalam penelitian ini meliputi perangkat keras, perangkat lunak komputer dan angket. Perangkat keras yang digunakan pada penelitian ini adalah laptop compaq 510. Sedangkan perangkat lunak yang digunakan adalah operasi sistem macromedia flash 8 .

Desain penelitian ini mengacu pada pengembangan ADDIE yang meliputi 5 tahap yaitu Analysis (analisis), Design (perencanaan), Development (produksi), Implementation (implementasi), Evaluation (evaluasi). Selanjutnya, untuk mengetahui tingkat kelayakan media ini di gunakan angket (kuisioner). Angket dalam bentuk kuesioner adalah kumpulan dari pernyataan yang diajukan secara tertulis yang digunakan untuk memperoleh informasi dari responden dalam arti tentang pribadinya atau hal yang diketahui (Arikunto, Suharsimi, 2006:140).

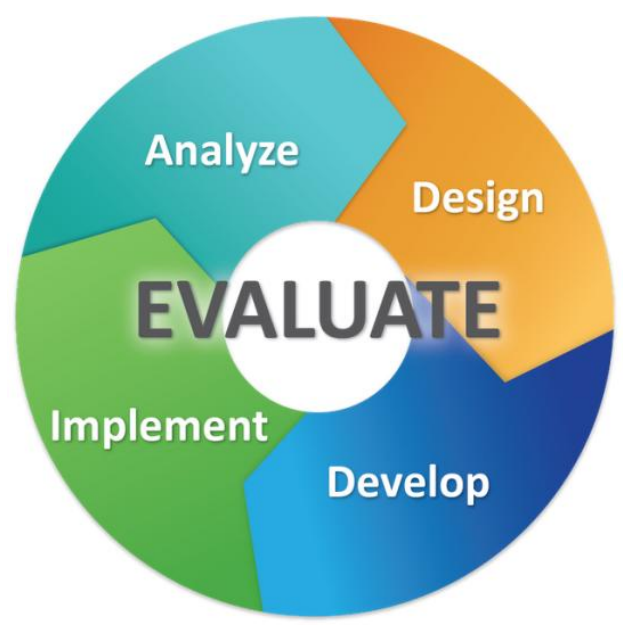

Gambar 1. Blog model pengembangan ADDIE
Metode angket digunakan
media pembelajaran, tampilan untuk mengukur indikator program program, dan kualitas teknis program. yang berkenaan dengan, isi program Angket menggunakan format respon 
empat poin dari skala Likert, dimana alternatif responnya adalah Sangat Setuju (4 point), Setuju (3 point), Kurang Setuju (2 point), dan Tidak Setuju (1 point).

Pada penelitian ini ditetapkan bahwa suatu kriteria atau bagian dalam bahan ajar fisika berbasis animasi komputer yang telah dibuat akan diperbaiki bila dari $75 \%$ jawaban responden angket Black Block Test merupakan jawaban negatif.

Untuk menganalisis data kita perlu mengkuantitatifkan hasil angket sesuai dengan indikator yang telah ditetapkan dengan memberikan skor sesuai dengan bobot yang telah ditentukan sebelumnya. Setelah data dikuantifkan, selanjutnya data ditabulasi. Untuk menghitung persentase dari tiap-tiap subvariabel dengan rumus:

$$
\begin{aligned}
& P(s)=\frac{s}{N} x 100 \% \\
& P(s)=\text { persentase sub variabel } \\
& S \quad=\text { jumlah skor tiap sub variabel }
\end{aligned}
$$

$N=$ jumlah skor maksimum

(Ali dalam Kristiningrum, 2007:41)

\section{HASIL DAN PEMBAHASAN}

\section{A. Hasil}

Setelah dilaksanakan tahaptahap rancangan dalam pembuatan media yang telah ditetapkan, telah dihasilkan media pembelajaran berbasis animasi dengan judul Hukum Newton tentang Gerak, dengan tampilan sesuai dengan standar animasi.

Dalam tampilan media ini terdiri atas menu dan sub-sub menu yang dapat dipilih masing-masing dengan memilih menu yang tersedia. Susunan menu dan tampilan dari media ini mengikuti diagram alir seperti pada gambar 2.

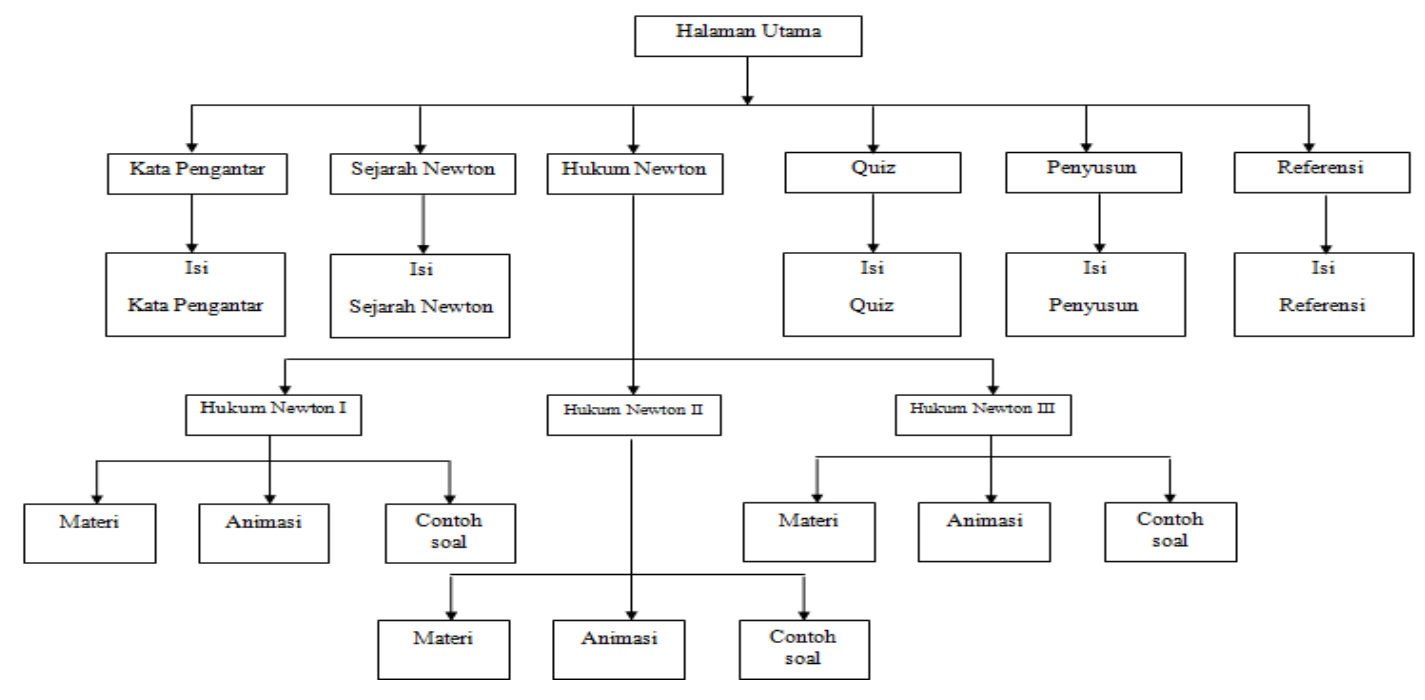

Gambar 2. diagram alir (Flow-Chart) 


\section{Media Penobelajarean Fisika}

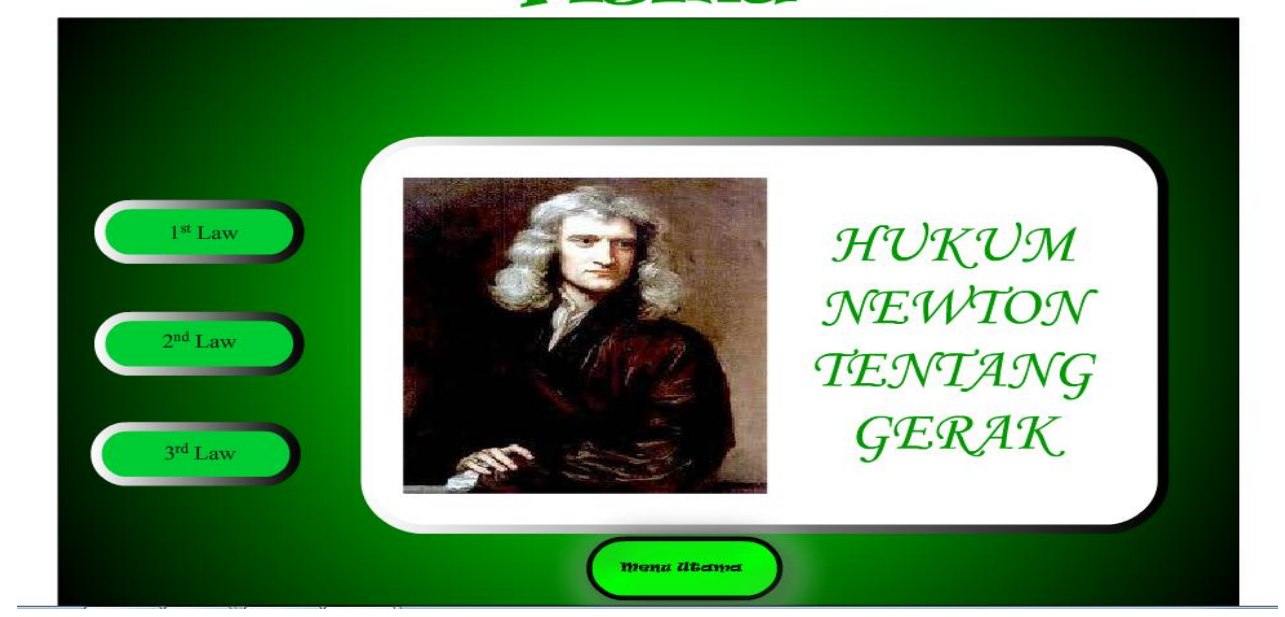

Gambar 2. Tampilan Awal Media

\section{B. Pengujian Program}

Program dianggap berhasil jika input, proses dan output aplikasi berjalan dengan baik sesuai dengan tujuan yang ingin dicapai. Untuk mengetahui kelebihan dan kekurangan program maka diperlukan suatu proses pengujian untuk menganalisis data berdasarkan kisi-kisi angket yang telah dibuat. Maksud dari analisis data yaitu untuk mengetahui kelayakan media sebagai media pembelajaran fisika pokok bahasan Hukum Newton Tentang Gerak untuk SMA kelas X. Pengujian angket media dilakukan dengan dua cara yaitu angket kepada beberapa ahli bidang studi fisika dan angket ahli perancangan media. Adapun hasil pengujian angket sebagai berikut :

1. Analisis skor angket ahli bidang studi Fisika

Berdasarkan hasil analisis angket ahli bidang fisika mengenai program media pembelajaran yang dikembangkan menghasilkan persentase sebesar $84,38 \%$ tergolong dalam katagori baik Aspek yang dinilai oleh para guru terhadap program ini adalah kesesuaian materi dengan kurikulum SMA, kesesuaian animasi dengan materi yang ingin disampaikan, kemampuan menarik minat siswa untuk belajar fisika melalui animasi ini, dan kemampuan animasi untuk menjadi alat bantu belajar mandiri. Dengan demikian dapat disimpulkan, bahwa dari segi materi media pembelajaran yang dikembangkan menarik dan dapat memotivasi siswa sehingga layak untuk dijadikan media pembelajaran fisika pada pokok bahasan hukum Newton tentang gerak.

2. Analisis skor angket pakar perancangan media

Berdasarkan hasil analisis angket dari pakar perancangan media mengenai program media pembelajaran yang dikembangkan menghasilkan persentase sebesar $84,27 \%$ tergolong dalam katagori 
baik. Dengan demikian dapat disimpulkan, bahwa dari segi tampilan dan teknis media pembelajaran yang dikembangkan layak untuk dijadikan media pembelajaran fisika pada pokok bahasan hukum Newton tentang gerak untuk SMA kelas X. Aspek penilaian meliputi tampilan, pemilihan warna, fungsi tombol, output dari menu, dan juga kemudahan akses alur yang teratur dari menu yang ada.

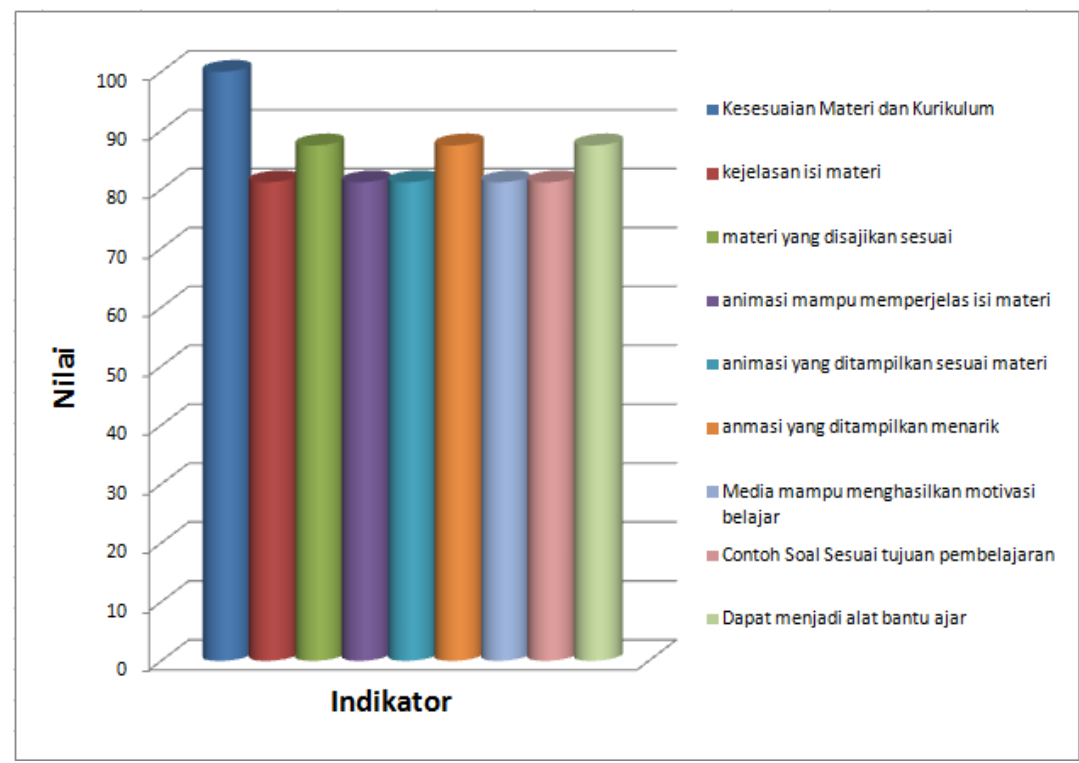

Gambar 4. Grafik Perolehan skor penilaian menurut guru fisika

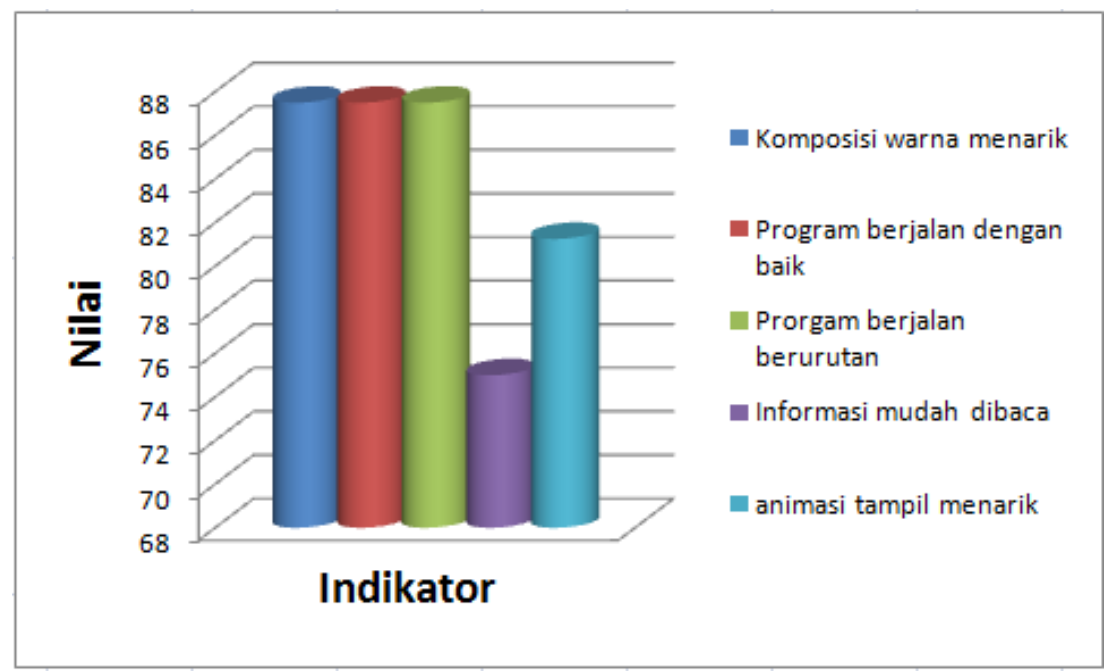

Gambar 5. Grafik Perolehan skor penilaian menurut pakar media

\section{Pembahasan}

Berdasarkan hasil pengujian yang telah dilakukan, menyatakan bahwa program ini dapat dimanfaatkan dalam pembelajaran fisika pokok bahasan Hukum Newton Tentang Gerak untuk SMA kelas X. Penggunaan program relatif mudah dan sederhana, hanya 
memasukan input (program) lalu tinggal meng-klik menggunakan mouse sehingga Output akan ditampilkan pada layar. Program ini telah memenuhi syarat kelayakan dengan kriteria, kesesuaian program bahan ajar fisika pokok bahasan Hukum Newton Tentang Gerak SMA kelas $\mathrm{X}$ sebesar $84,03 \%$ atau termasuk dalam kategori baik (B), dan kualitas teknisnya sebesar 84,27\% temasuk dalam kategori baik (B). Maka dari hasil pengujian tersebut, program yang dikembangkan layak dijadikan sebagai media pembelajaran fisika pokok bahasan Hukum Newton tentang gerak untuk SMA kelas X.

\section{KESIMPULAN}

Dari hasil penelitian yang telah dilakukan dapat diambil kesimpulan bahwa, Telah dibuat aplikasi paket belajar fisika berbasis animasi komputer materi pokok bahasan Hukum Newton tentang gerak untuk SMA kelas X. Berdasarkan analisis terhadap program ini, untuk kriteria kesesuaian program terhadap bahan ajar fisika pokok bahasan hukum newton tentang gerak dalam kategori baik $(85,42 \%)$, dan kualitas teknisnya temasuk dalam kategori baik $(84,27 \%)$. Dengan demikian program yang dikembangkan layak dijadikan sebagi media pembelajaran dan dapat dimanfaatkan dalam pembelajaran Fisika pokok bahasan hukum Newton tentang gerak untuk siswa SMA kelas $\mathrm{X}$.

\section{DAFTAR PUSTAKA}

Arikunto, Suharsimi. 2008. DasarDasar Evaluasi Pendidikan. Jakarta: Bumi Aksara.

Kristiningrum. 2007. Pengembangan Multimedia Pembelajaran Interaktif dengan Macromedia Authorware 7.0 Pada Materi Fisika Sekolah Menengah Atas (SMA) Pokok Bahasan Kinematika Gerak Lurus. Skripsi. Semarang: Unnes.

Prabu, A. Markus, I.M. 2006.

Efektifitas Penggunaan Software

Pesona Fisika dalam

Pembelajaran Fisika di SMA

Santa Ursula BSD

Sardiman, Arief et al. 2008. Media

Pendidikan (Pengertian

Pengembangan Pemanfaatannya).

Jakarta: Rajawali.

Sugiharti, P., 2005, "Penerapan Teori Multiple Intelligence dalam Pembelajaran Fisika," [ Versi elektronik] Jurnal Pendidikan Penabur 5, 29-42. 